\title{
TALENT MANAGEMENT IN IMPROVING THE EMPLOYEES PERFORMANCE OF PT PLN (PERSERO) TJBB APP CAWANG
}

\author{
Asri Nur Mutiara ${ }^{* 1}$, Aida Vitayala Hubeis ${ }^{* *}$, and Anggraini Sukmawati***) \\ *) School of Business, Bogor Agricultural University \\ Jl. Pajajaran, Bogor 16151 \\ **) Department of Communication Science and Community Development, Faculty of Human Ecology, \\ Bogor Agricultural University \\ Jl. Kamper, Campus IPB Dramaga Bogor 16680 \\ ${ }^{* * *}$ Departement of Management, Faculty of Economics and Management, Bogor Agricultural University \\ Jl. Agatis, Campus IPB Dramaga Bogor 16680
}

\begin{abstract}
Human resources are the key to the company's success in achieving company's goals. One of the things that affect the performance of employee is the employee's talent. PT PLN (Persero) is a company that implements talent management to manage human resource in order to achieve maximum performance. This study aims to analyze the implementation of talent management, to analyze its impact in improving the employee's performance, and to formulate the implementation of managerial implications for the employee development of PT PLN (Persero) APP Cawang. This research was conducted using a questionnaire towards 68 employees of first-line and middle management at PT PLN (Persero) APP Cawang. The data was analyzed using Structural Equation Modelling - Partial Least Squares (SEM-PLS). The conclusion of this study is the company should provide some development programs for talented employees to improve their performance. The results show that there is a significant relationship between talent management variables and the employee's performance in PT PLN (Persero) TJBB APP Cawang. Talent management is very influential on employee performance in PT PLN (Persero) TJBB APP Cawang, which is $38.2 \%$ and the remaining $61.8 \%$ is influenced by other factors.
\end{abstract}

Keywords: state-owned enterprises (BUMN), first-line management, middle management, employee performance, SEM, talent management

\begin{abstract}
Abstrak: Sumber daya manusia merupakan kunci kesuksesan perusahaan dalam mencapai tujuan perusahaan. Salah satu hal yang mempengaruhi kinerja karyawan adalah talenta karyawan itu sendiri. PT PLN (Persero) adalah perusahaan yang menerapkan manajemen talenta untuk mengelola sumber daya manusia agar dapat mencapai kinerja maksimal. Penelitian ini bertujuan untuk menganalisis pelaksanaan manajemen talenta, menganalisis pengaruh manajemen talenta dalam meningkatkan kinerja karyawan, dan merumuskan pelaksanaan implikasi manajerial untuk pengembangan karyawan PT PLN (Persero) APP Cawang. Penelitian ini dilakukan dengan menggunakan kuesioner terhadap 68 karyawan manajemen lini pertama dan manajemen menengah di PT PLN (Persero) APP Cawang. Analisis data menggunakan Structural Equation Modeling - Partial Least Squares (SEM-PLS). Simpulan dari penelitian bahwa perusahaan memberikan program pengembangan bagi karyawan yang bertalenta untuk meningkatkan kinerja. Hasil penelitian menunjukkan terdapat hubungan yang signifikan antara variabel manajemen talenta dengan kinerja karyawan di PT PLN (Persero) TJBB APP Cawang. Di PT PLN (Persero) TJBB APP Cawang, manajemen talenta sangat berpengaruh besar terhadap kinerja karyawan, yaitu sebesar $38.2 \%$ dan sisanya $61.8 \%$ dipengaruhi oleh faktor lain di luar model.
\end{abstract}

Kata kunci: BUMN, kinerja karyawan, manajemen lini pertama, manajemen menengah, manajemen talenta, SEM

\footnotetext{
${ }^{1}$ Corresponding author:

Email: asrinurmutiara@rocketmail.com
} 


\section{INTRODUCTION}

The talents of an employee resulting from two conditions; taken from the outset before joining the company and formed during the human resources development program in the companies (Iqbal et al. 2011). Talents are the employees who are identified to have the potential to be the future leader of the company (Pella and Inayati, 2011). Talent management is a dynamic and comprehensive process to develop the highest potential employees within an organization through direct and integrated development that is carried out by related leaders in the company and it relates to the activities to find, select, develop and maintain the talented employees (Pella and Inayati, 2011).

The standard of company's performance is how the vision, mission and goals of the company are achieved. Nowadays the process or efforts to achieve the company's goals are known as performance management. Performance is also defined as a result of the work or work achievement (Lopes et al. 2014). Performance is the result of a work which has strong ties to company's strategic goals, customer satisfaction and has economic contribution (Wibowo, 2007). According to Simanjuntak (2011), performance is the resulted achievement of the implementation of specific tasks. Employee's performance is work results that are achieved by an employee within certain period based on work standard established by the company (Suroso and Siahaan, 2006). Individual performance is determined by three factors; talents and abilities, perceptions on roles and efforts. An employee who has talents and capabilities as well as the role does not guarrantee to have a high-performance. To generate a high performance; an employee has to be motivated to fight (Irawati et al. 2017).

The compliance of electric power needs for people is the fundamental requirement for the economic growth of the country. Because of its crucial needs, then all supporting infrastructure such as HR, NR and technology related to it has to be optimally operated. The country's power generation company (PT PLN) Persero is the State-owned enterprises (BUMN) that are engaged in the provision of electric energy in Indonesia. The role of HR is very important in advancing the company. Human resources are the key success of a company to run the business as well as to achieve the company's goals. Human resources are one of the basic movers for the continuity of company's activities.
The state enterprise should be seriously and well managed by competent people so it can support the company's programmes. One of the things that impact the employee's performance is the talent of employee itself (Putera and Taufiq, 2015). Each individual has different talent levels in accordance with the system and values on them. The higher the assessment of competence levels against the task or company's activities, the higher the employee's performance against its task or activities.

To pertain to the human resources management, PT PLN (Persero) has already issued some policies as an effort to develop and maintain its employees. For example, PT PLN (Persero) has published the Director's decision letter regarding to career coaching and employees. The mastery of position competence is required at every level of employee's competence (Basic, Specific, System, Optimization, Advanced and Integration).

In line with this, the HR perspective performance of PT PLN (Persero) has focussed on two major domains starting in 2013; human capital readiness and organizational capital readiness. It is increasingly asserted that management of competence and HR level readiness in dealing with the company's changes is the most important thing that should be concerned. The next talent management control was targeted as one of KPI points in 2014.

In KPI 2014, talent management was conducted as one of the important efforts to form the cadres. These cadres are very important for the company because they will be the core of company's sustainability in the future. The function of the cadres' recruitment in this activity is to prepare some candidates who are ready to continue running the work to achieve the overall goals of the company according to its vision and mission.

Some companies have found some new talents and skills of their employees. Nowadays, the problem is talent management in the company has not yet run very well. The company has to have a talent management to separate between talented employees and employees with average ability, so that it can improve the performance of employees.

In 2017, top and middle positions of the company were expected to have the readiness of good talent management which were classified into employees who 
had better skills and employees who had an average ability to run the company's strategy so the company's goals could be reached. Employee's talent was marked by the company based on the standard applied there. Talent management was used to replace the first or top position in this company.

PT PLN (Persero) TJBB APP Cawang is a company which provides services in distribution, operation and maintenance of main relay station and transmission in West Java region for the public needs. Area of East Jakarta has those talented employees but they do not have the right position for that. Talent management is needed to make those talents useful and thus the employees have a better job opportunity. Based on that issue, the title for this study is Talent Management in Improving the Performance of Employees of PT PLN (Persero) TJBB APP Cawang.

Some previous studies only investigated talent management with other variables such as organizational commitment, employees' turnover and climate. Those were studied by Rana and Abbasi (2013); Rana and Abbasi (2013); Nobarieidishe et al. (2014); Kusumowardani and Suharnomo (2016); and Ingram (2016).

Other researches about talent management and performance are studied by Darna et al. (2014); Nisa et al. (2016); Syahputra and Syarifuddin (2016); Rachmadinata and Ayuningtias (2017). The result showed that there is a positive correlation between talent management and performance. The previous researchers that investigated talent management variable as a strategy in a company or organization were Thunnissen and Arensbergen (2014); Sukoco and Fadillah (2016); Rachmawati (2017).

The purpose of this research is to analyze the implementation of talent management, to know the influence of talent management in improving employees' performance and to state the implementation of managerial implication for development of employees of PT PLN (Persero) TJBB APP Cawang. This study is limited because it only focused on the employees of PT PLN (Persero) TJBB APP Cawang who already officiate first line management and middle management.

The differences between this research and other previous researches are on the samples taken that are first line and middle management employees, and this study uses one variable that is talent management and performance. Moreover, the performance dimensions used for this study consist of six dimensions.

\section{METHODS}

The research was conducted in PT PLN (Persero) TJBB APP Cawang which is located in Cililitan Besar Street No. 1, Cawang - Cililitan, East Jakarta by using questionnaire towards 219 employees with first line management and middle management level. Research data were collected in August to October 2017.

The data used is primary and secondary data. The primary data was obtained based on questionnaires and interviews with GM of PLN TJBB, Mr Trino Erwin. The questionnaires were used to mark employee performance and talent management for quantitative analysis needs. The scale used to measure respondent responses is the Likert scale. The responses which support the statement are given highest score (5) and responses which do not support are given lowest score (1).

The secondary data used was obtained from various sources such as books, journals, articles, thesis, company website and other relevant sources. The samples or examples taken in this research were based on Slovin's formula (Umar, 2004). Based on that formula, there were 68 respondents as samples and sampling proportion. It used probability sampling by simple random sampling method.

The processing technique and data analysis in this research use: (1) frequency descriptive analysis, modus and percentage to analyze the perception of talent management and employees' performance, (2) test of validity, (3) reliability, and (4) analysis of structural equation modelling (SEM) trough partial least squares (PLS) approach. Descriptive research is used as the research design.

The data of this study is analysed by using the Structural Equation Modelling (SEM) with the Partial Least Squares (PLS) approach. It is used to know the impact of exogenous latent variable towards endogenous latent variable.

The exogenous latent variable for this study is talent management and endogenous latent variable is 
employee performance. There are three dimensions for talent management variable; recruiting and selecting, maintaining and developing. Otherwise employee performance variable has six dimensions; there are quality, quantity, timeliness, cost effectiveness, needs for supervision and interpersonal impact.

Latan and Ghozali (2012) stated that SEM-PLS is a method that is used to cover the weaknesses of regression method. SEM-PLS will test the measurement model and structural model. PLS-SEM aims to test the predictive correlation among constructs whether the constructs relate to or impact one another (Latan and Ghozali, 2012).

Measurement model (outer model) is conducted to assess the validity and reliability model. The criteria to assess the measurement model are convergent validity, discriminant validity and composite reliability.

Convergent validity test in PLS with reflective indicator is assessed based on the loading of indicator factor that measures the construct. The individual reflexive is rated high when it is correlated over 0.70 against the measured construct. Ghozali (2008) said the scale of loading value measurement used for the early stage of research is $0.5-0.6$, which will be considered enough.

Discriminant validity test is a reflexive indicator measurement based on cross loading with its latent variables. The other method is by comparing the value of Square root of average variance extracted (AVE) of each variable with the correlation between other variables in model. When the initial measurement value of both methods is better than the value of other variables in model, it can be inferred that these variables have a good discriminant validity value or vice versa.

Composite reliability measures the exact reliability of a construct. Rule of thumb of cronbach's alpha value and composite reliability must be over than 0.7 although the value of 0.6 is still acceptable (Sukoco and Viciana, 2014).

The structural model (inner model) is used to predict the causality among the latent variables. This model is evaluated by using R-Square to dependent construct, path coefficient value or $t$-value each path for a real level in hypothesis test. The higher the R-Square, the better the model will be.
In line with the thought and theory and also theoretical framework mentioned before, this research has only one hypothesis that is $\mathrm{H} 1$ talent management impacts employee performance.

This hypothesis means that supposedly the better talent had by the employee then their performance will be greater. Otherwise, when employee's talent is decreased then supposedly their performance will be also worse.

There is also research on theoretical framework to discuss the problems and theories found. To know the impact of talent management towards employee performance, there is a theoretical framework drafted as showed in Figure 1. The hypothesis formulated in this research is as follows: H1(talent management impacts employee performance).

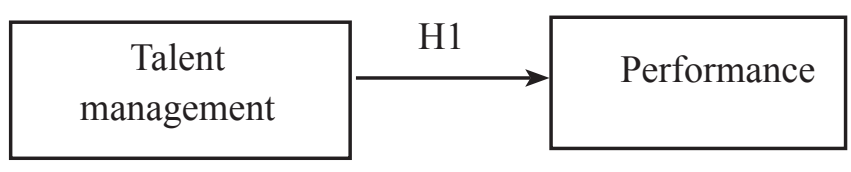

Picture 1 Research framework

\section{RESULTS}

\section{Validity Test}

According to Syahputra and Syarifuddin (2016), doing validity test, measuring the validity of each research dimension, is based on Kaiser-Mayer - Olkin Measure of Sampling Adequacy (KMO). The valid KMO is equal or more than $0.5(\geq 0.5)$ and valid number for Barlett Test of Sphericity is equal or less than 0.05 ( $\leq$ 0.05 ). The result of factor analysis to test the validity is showed in Table 1.Based on the table, the overall result shows that every dimension of each variable is valid with the KMO more than 0.5 and Barlett Test of Sphericity is less than 0.5 .

\section{Reliability Test}

Cronbach's Alpha Reliability is used to test the reliability. The reliable construct is valid if it is more than 0.7. There are three dimensions of dependent variable and six dimensions of independent variable. The result of Cronbach's Alpha Reliability of dependent and independent variable in this research in Table 2. 
Table 1. The Value of kaiser-mayer-olkin measure sampling adequacy, barlett test of sphericity on pre-test $(\mathrm{n}=30$ )

\begin{tabular}{lllcl}
\hline Variable & Dimension & KMO & Barlett's Test of Sphericity & Note \\
\hline Talent Management & Recruiting and selecting & .791 & .000 & Valid \\
& Maintaining & 4 & .000 & Valid \\
& Developing & 1 & .000 & Valid \\
Employee Performance & Quality & .592 & .000 & Valid \\
& Quantity & .643 & .000 & Valid \\
& Timeliness & .805 & .000 & Valid \\
& Cost effectiveness & .521 & .000 & Valid \\
& Needs to Supervision & .762 & .000 & Valid \\
& Interpersonal Impact & .775 & .000 & Valid \\
\hline
\end{tabular}

Table 2. The research dimension reliability

\begin{tabular}{llcc}
\hline Variable & Dimension & Cronbach's Alpha Reliability & Note \\
\hline Talent Management & Recruiting and selecting & .827 & Very reliable \\
& Maintaining & .780 & Reliable \\
& Developing & .893 & Very reliable \\
Employee Performance & Quality & .907 & Very reliable \\
& Quantity & .756 & Reliable \\
& Timeliness & .875 & Very reliable \\
& Cost effectiveness & .809 & Very reliable \\
& Needs to Supervision & .760 & Reliable \\
& Interpersonal Impact & .944 & Very reliable \\
\hline
\end{tabular}

The Implementation of Talent Management and Employee Performance in PT PLN (Persero) TJBB APP Cawang

The exogenous latent variable for this study is talent management and endogenous latent variable is employee performance. There are three dimensions for talent management variable; recruiting and selecting, maintaining and developing. Otherwise employee performance variable has six dimensions; there are quality, quantity, timeliness, cost effectiveness, needs to supervision and interpersonal impact. The result is based on respondents' answer about talent management and employee performance variables in Table 3.

In Table 3, dimension of recruiting and selecting has $69.12 \%$ and the frequent modus is 4 . It means that employees agree in recruiting and selecting talented employee based on their skills. The maintaining dimension has $67.65 \%$ and frequent modus is 4 . It means that employees agree that compensation given by the company is based on the commitment to give the best performance. The percentage of developing dimension is $67.65 \%$ and its frequent modus is 4 , which means that employees agree to have a periodical executive coaching to improve their performance.

In the employee performance variable, percentage of quality dimension is $75 \%$ and its frequent modus is 4. This means that employees agree that the resulted output has high accuracy. The percentage of quantity dimension is $68 \%$ and its modus is 4 . It means that employees agree that work achievement level is equal to the company's expectation. Timeliness dimension has $64.71 \%$ and its modus is 4 . That means employees agree to complete the work on time. The percentage of cost effectiveness is $79.42 \%$ and its frequent modus is 4 , which means that employees agree to streamline the budget. The percentage of needs to supervision is $77.94 \%$ and the frequent modus is 4 , which means that the employees agree a good teamwork attitude can improve the performance. The last is interpersonal impact dimension that has $67.65 \%$ and its frequent modus is 4 . It means that employees agree that self-developing in the company can improve their performance. 
Table 3. Number of respondents based on talent management and performance variables

\begin{tabular}{llcc}
\hline Variable & Dimension & Modus & Percentage (\%) \\
\hline Talent Management & Recruiting and selecting & 4 & 69.12 \\
& Maintaining & 4 & 67.65 \\
& Developing & 4 & 67.65 \\
Employee Performance & Quality & 4 & 75 \\
& Quantity & 4 & 66.18 \\
& Timeliness & 4 & 64.71 \\
& Cost effectiveness & 4 & 79.42 \\
& Needs to Supervision & 4 & 77.94 \\
& Interpersonal Impact & 4 & 67.65 \\
\hline
\end{tabular}

\section{The Impact of Talent Management on Employee Performance}

Structural Equation Modelling (SEM) is a method that is used to cover the weaknesses of regression method. SEM is classified into two approaches. They are covariance based- structural equation modelling (CBSEM) approach and variance based SEM or partial least square (PLS) approach. The analysis of PLS-SEM consists of two sub models, i.e. measurement model or often mentioned as outer model and structural model or often called inner model (Ghozali and Latan, 2012). Measurement model shows how manifest variable or observed variable represents the latent variable to be measured. Moreover, structural model shows the estimation strength between latent and construct variables.

\section{The Evaluation of Measurement Model}

Measurement model shows how manifest or observed variable represents latent variable to be measured. The evaluation of measurement model of PLS-SEM can be done by evaluating the measurement model or by confirmatory factor analysis (CFA) that is by testing the validity and reliability of latent constructs.

When there is an indicator that has loading factor $<0.5$, the calculating to the previous model should be done again, thus it results in the loading factor of all reflective indicator $>0.5$ as the criteria of convergent validity test of latent construct (Ghozali, 2008). Moreover, the model has great validity when its latent variable and reflective indicator have AVE $>0.5$. The analysis in Table 4 shows the AVE of needs for supervision and maintaining dimension is $<0.5$. Thus it can be said that PLS model has not yet filled the criteria of good convergent validity, so that indicator of needs for supervision and maintaining dimensions which have smallest loading factor X2.5 and Y5.3 have to be removed from the model.

Next is the test of discriminant validity that is done through a basic that different construct denomination (manifest variable) should not be highly correlated (Ghozali, 2008). In the first model, the cross loading of each indicator is not fully qualified discriminant validity so that the indicator has to be removed from the model. There are X1.3, Y1.5, Y4.1, Y4.3 and Y6.1. After removing indicators X2.5, X1.3, Y1.5, Y4.1, Y4.3, Y5.3 and Y6.1, the whole indicator then has a loading factor $>0.5$ as well as AVE of all variable $>0.5$ thus it can be said that final PLS model has qualified as good convergent validity. The AVE final model is seen in Table 5 and picture of loading factor in measurement can be seen in Figure 2 .

The next measurement is reliability test towards model used in order to prove the accuracy, consistency and instrument exactness in measuring the constructs. It is said reliable if the composite reliability towards latent variable is $>0.7$. The result mentioned in Table 5 shows that all latent constructs have a good reliability, are accurate and consistent with the value of composite reliability of each construct, which is more than 0.7 .

The test on discriminant validity shows that all indicators have a cross loading value that is more than its latent variable and do so when it is compared with other latent variables. So it can be said that the model has qualified as discriminant validity.

The Evaluation of Structural Model 
The structural model indicates the estimation strength between latent variable and constructs. The indicator of latent variable in PLS-SEM can be reflective or formative (Ghozali and Latan, 2012). The result of bootstrapping in Table 6 consists of talent management as independent variable and employee performance as dependent variable.

\section{The Result of Data Analysis of the Impact of Talent} Management towards Employee Performance

Talent management has a significantly direct impact on employee performance. According to the research result, talent management has a significantly positive impact to employee performance, i.e. 0.382. Then based on T-statistics, it is 6.054 more than T-table that is 1.96 on belief interval as $95 \%$ in 5\% alpha level. On the other hand, the Path Coefficient 0.618 or $61.8 \%$ is affected by other factors which are out of model that impact employee performance such as knowledge management, compensation, communication and organizational climate.

The indicator reflecting the employee performance in this study is the teamwork can improve employee performance. A team can work together to achieve the same goal. The employees can get success if they are supported and also support other employees. A success can be achieved through an effective teamwork as well as the skills that should continue to be improved. There is no use if a high skilled employee cannot work together in a team. Thus a good teamwork can improve the performance of the person.

The performance assessment can be resulted from compounding the assessment of soft skill and hard skill which is called talent assessment. When their soft skill is low, their hard skill will be automatically low and vice versa. Furthermore, if their soft skill is high, their hard skill will also be high or better. Thus the employee can be said as a talented employee when they have individual competence and their performance score can reach the minimum score 301 .

In this study, the writer analyses the implementation

Table 4. Average Variance Extracted (AVE) and first model of composite reliability

\begin{tabular}{lcc}
\hline Dimension & AVE & Composite Reliability \\
\hline Impact & 0.756 & 0.938 \\
Cost Effectiveness & 0.644 & 0.899 \\
Needs to Supervision & 0.495 & 0.826 \\
Timeliness & 0.709 & 0.924 \\
Quality & 0.724 & 0.928 \\
Quantity & 0.530 & 0.845 \\
Maintaining & 0.468 & 0.811 \\
Developing & 0.604 & 0.883 \\
Recruiting and Selecting & 0.508 & 0.834 \\
\hline
\end{tabular}

Table 5. Average Variance Extracted (AVE), and final model of composite reliability

\begin{tabular}{lcc}
\hline Dimension & AVE & Composite Reliability \\
\hline Impact & 0.859 & 0.960 \\
Cost Effectiveness & 0.717 & 0.883 \\
Needs to Supervision & 0.577 & 0.844 \\
Timeliness & 0.709 & 0.924 \\
Quality & 0.704 & 0.904 \\
Quantity & 0.530 & 0.845 \\
Maintaining & 0.535 & 0.820 \\
Developing & 0.604 & 0.882 \\
Recruiting and Selecting & 0.598 & 0.856 \\
\hline
\end{tabular}




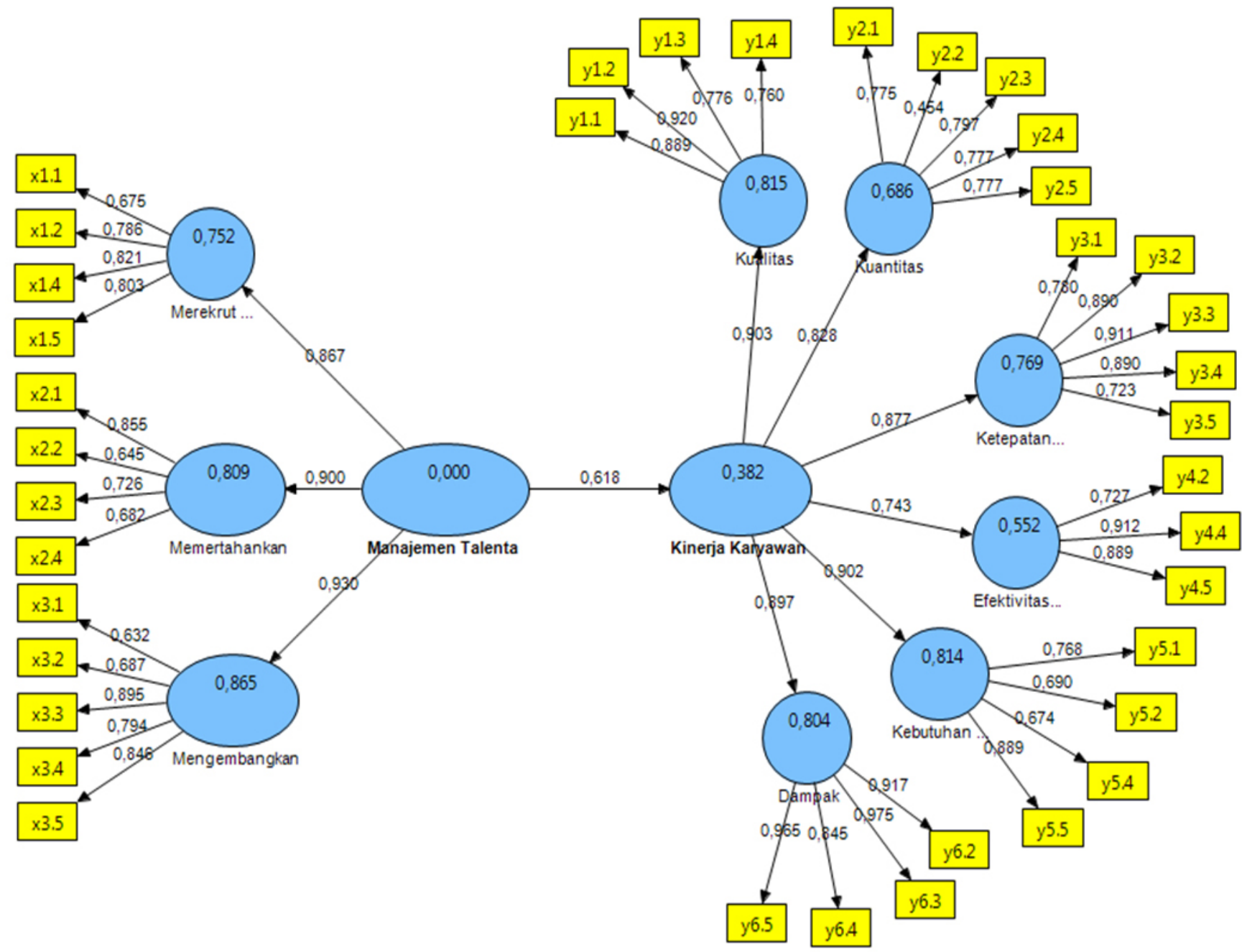

Note

$\mathrm{X} 1.1$

$\mathrm{X} 1.2$

$\mathrm{X} 1.4$

$\mathrm{X} 1.5$

$\mathrm{X} 2.1$

$\mathrm{X} 2.2$

$\mathrm{X} 2.3$

$\mathrm{X} 2.4$

$\mathrm{X} 3.1$

$\mathrm{X} 3.2$

$\mathrm{X} 3.3$

$\mathrm{X} 3.4$

$\mathrm{X} 3.5$

$\mathrm{Y} 1.1$

Y1.2

$\mathrm{Y} 1.3$

Y1.4

Y 2.1

Y 2.2
$=$ Talent Employees

$=$ Talent Employees based on employees skills

$=$ Key position

$=$ Talent Mapping

$=$ Strategy in maintaining the best talent

$=$ Compensation

$=$ Compensation of commitment-based

$=$ Compensation of commitment-based to the company

$=$ External training

$=$ Executive coaching

$=$ Training program

$=$ Workshop

$=$ Internal training

$=$ Innovative

$=$ Employee skill

$=$ Do the job skillfully

$=$ Accuracy

$=$ Work achievement level

$=$ Output resulted can be measured by denomination
Y 2.3

Y 2.4

Y2.5

Y 3.1

Y3.2

Y 3.3

Y 3.4

Y 3.5

Y 4.2

Y 4.4

Y4.5

Y 5.1

Y 5.2

Y 5.4

Y 5.5

Y 6.2

Y 6.3

Y 6.4

Y 6.5
$=$ Output resulted can be measured by denomination

$=$ Work quantity level

$=$ Task ability level

$=$ Complete the work before

$=$ The job is always completed on time

$=$ Do not delay the work

$=$ Focus on the job

$=$ The over time is to do another job

$=$ Maximize the result

$=$ Streamline the budgets

$=$ Do not waste for new

$=$ Periodic coaching

$=$ Do not need control intervention

$=$ Periodical feedback

$=$ Have good teamwork

$=$ Self-actualization

$=$ Teamwork

$=$ Self-developing

$=$ Self-competance

Figure 2. Loading factor in final measurement model 
Table 6. Path Coefficient and t-statistics of total impact

\begin{tabular}{lccc}
\hline & Path Coefficient & T-statistic & R square \\
\hline Talent Management $\rightarrow$ Employee Performance & 0.618 & 6.054 & 0.382 \\
\hline
\end{tabular}

Note: $\left.{ }^{*}\right)$ T-statistic $>$ T-table (1.96) means significant impact on level 5\%.

of talent management and performance of PT PLN (Persero) TJBB APP Cawang, the impact of talent management in improving the employees' performance, and the implementation of managerial implication in developing the employees. The hypothesis result of research analysis shows that there is a significant impact between talent management and performance of employees of PT PLN (Persero) TJBB APP Cawang.

The result of this study supports the previous study done by Nisa et al. (2016). That study was to investigate the description of talent management implementation, knowledge management, and employee performance, as well as analyses and explains the impact among variables. The implementation of talent management and knowledge management in PT. PLN (Persero) Distribution of East Java, Surabaya has already been well done. Both variables showed significant positive impact to the employee performance variable when they were tested together but the impact was not significant when partially tested. This was due to some barriers in its implementation. It is similar to the study done by Rachmadinata and Ayuningtias (2017) about the impact of talent management and competence to the performance of employees. Additionally, Ardyanfitri had done a study about the impact of talent management towards job satisfaction of employees in University of Telkom. It resulted that recruiting, selecting and developing the talents significantly impacted the employee job satisfaction.

The interview with $\mathrm{Mr}$ Trino Erwin as GM PLN (Persero) TJBB results to create a talent pool especially in TJBB to fill certain positions in talent management program. All employees fill out SIMKPNAS (Information System of National Employee Performance) in order to assess the performance of employees. The criteria for employees who can follow talent management program are a minimum two-year working period, under 50 years old and other specific assessment criteria (based on the company policy). There are some ways to select talented employees; (1) define clearly the needs for mostly needed talents, (2) describe the challenging opportunities, (3) use the marketing or promotion in recruiting the talents, (4) specify the period of time placement, and (5) reduce the risks.

\section{Managerial Implications}

This study results in the main finding that is talent management can improve the performance of employees. After studying the result of this research, we can formulate some managerial implications. The company leadership can maintain talented employees by providing career development, continuing education, and giving compensation in cash or non-cash. In addition, the leadership can also develop talented employees by organizing some programs that can improve self-potency of employees, such as training, workshop, seminar, and external training which is held once in three months outside or inside the city. By holding these programs, the talented employees can improve their knowledge and prepare themselves to follow talent management programs at the expected positions.

To improve the employees' performance, the company's leadership can give interesting rewards to affect the employees' interests to accomplish and innovate, to employees' regeneration, to give fair chance for young employees for their career development, and to affirm the discipline to the employees. By giving these positive things, the employees will be more satisfied, and in turn it will improve their performance.

\section{CONCLUSIONS AND RECOMMENDATIONS}

\section{Conclusions}

The result of the research indicates that the implementation of talent management in PT PLN (Persero) TJBB APP Cawang consists of three dimensions; recruiting and selecting, maintaining and developing. In recruiting and selecting the employees, the company implements a good strategy so that it can get employees with their best talents. 
The great talent management dimension which can impact employees' performance is developing, by which each employee has the same rights to participate in training programs, such as training, workshop and seminar in order to improve their performance. Another dimension which has great impact to employee performance is interpersonal impact, by which the company provide the opportunities to its employees to improve their competence.

The company can maintain its employees by giving career development or further education. Besides, the leadership can also develop these talented employees by holding some programmes in which they can improve their self-competence. In improving the employee performance, the company's leadership can give interesting reward to affect the employees' interests to accomplish and innovate in their work. By giving these positive things, the employees will be more satisfied and thus their performance will be automatically improved.

The result of this study is similar to the result of study done by Nisa et al. (2016) about the implementation of talent management and knowledge management in PT PLN (Persero) Distribution of East Java. That result said that it had a significant positive impact towards employees' performance variable.

\section{Recommendations}

There is some recommendations for PT PLN (Persero) TJBB APP Cawang i.e. providing more development programs for the employees so as to enrich both their knowledge and skills, and thus to improve their performance. We recommend that the employees who can participate in these talent management programs at least have one-year experience and are 35 years old. Therefore, the company can recruit and select many employees to be participated in the talent management programs.We also recommendations to do further researches on other factors which can impact employee performance and to use other variables in studying the impact of talent management towards performance and its implications towards the performance of employees of PT PLN.

\section{REFERENCES}

Darna N, Basari MA, Faruk M. 2014. Mewujudkan tata kelola pemerintahan yang baik (good governance): melalui optimalisasi penilaian kinerja, manajement talenta dan manajemen kinerja karyawan negeri sipil. Riset Bisnis dan Manajemen 4(2): 2-18.

Ghozali I. 2008. Structural Equation Modelling (SEM): Metode Alternatif dengan Partial Least Square (PLS). Ed ke-2. Semarang: Badan penerbit Universitas Diponegoro.

Ingram T. 2016. Relationships between talent management and organizational performance: the role of climate for Creativity. Journal Entrepreneurial Business and Economics 4(3):195-205.https://doi.org/10.15678/ EBER.2016.040315.

Irawati A, Sudarsono, B, Lestari L. 2017. Pengaruh manajemen bakat dan pengelolaan sumber daya manusia terhadap kinerja karyawan PT Jawa Pos Media Televisi (JTV) di Surabaya. Jurnal Manajemen 1(3): 210-224.

Iqbal S, Qureshi TM, Khan MA, Hijazi ST. 2011. Talent management is not an old wine in a new bottle. African Journal of Business Management 7(35): 3609-3619.

Kusumowardani A, Suharnomo AK. 2016. Analisis pengaruh manajemen talenta dan global mindset terhadap kinerja karyawan dan turnover intention dengan komitmen organisasi sebagai variabel intervening (studi pada karyawan PT Cipta Busana Mandiri Demak). Jurnal Manajemen 5(3): 1-15.

Latan H, Ghozali I. 2012. Partial Least Squares (PLS) Konsep, Teknik, dan Aplikasi SmartPLS 2.0M3 untuk Penelitian Empiris. Semarang: Badan penerbit Universitas Diponegoro.

Lopes SA, Sarraguca JMG, Duarte ME. 2014. A new approach to talent management in law firms integrating performance appraisal and assessment center data. International Journal of Productivity and Performance Management 64(4): 523-543. https://doi.org/10.1108/IJPPM08-2013-0147.

Nisa RC, Astuti ES, Prasetya A. 2016. Pengaruh manajemen talenta, manajemen perngetahuan terhadap kinerja karyawan (studi pada karyawan PT. PLN (Persero) distribusi Jawa Timur, Surabaya). JAB Universitas Brawijaya 39(2):141-148. 
Nobarieidishe S, Chamanifard R, Nikpour A. 2014. The relationship between talent management and organizational commitment in international division of Tejarat Bank, Iran. European online. Journal of Natural and Social Sciences 3(4):1116-1123.

Pella DA, Inayati A. 2011. Talent Management: Mengembangkan SDM untuk Mencapai Pertumbuhan dan Kinerja Prima. Jakarta: PT Gramedia Pustaka Utama.

Putera DP, Taufiq. 2015. Model aplikasi pemetaan kompetensipegawaiPTPLN wilayah Kalimantan selatan dan tengah. Jurnal AdBispreneur 11(2):1181-1190.

Rana AH, Abbasi AS. 2013. Impact of talent management and employee turnover intention on organizational efficiency - a case of telecommunication sector of Pakistan. Journal of Management Research 25(3): 637-642.

Rachmadinata NS, Ayuningtias HG. 2017. Pengaruh manajemen talenta terhadap kinerja karyawan Lintasarta kota Jakarta. Jurnal Manajemen Indonesia 17(3):197-204.

Rachmawati M. 2012. Strategi untuk menerapkan talent management (manajemen talenta) dalam perusahaan. International Journal of Management, Economics and Social Sciences 1(2): 33-41.

Simanjuntak PJ. 2011. Manajemen dan Evaluasi Kinerja. Jakarta: Lembaga Penerbit Fakultas
Ekonomi Universitas Indonesia.

Sukoco BM, Viciana V. 2014. Sistem organisasi kognitif dan efektif dan pengaruhnya terhadap kinerja apotek di Surabaya: efek moderasi orientasi kewirausahaan. Jurnal Manajemen Teknologi 13(1):22-39.

SukocoI,FadillahAR.2016.Analisisstrategimanajemen talenta menggunakan pendekatan kompetensi organisasional pada PT PINPAD (Persero) Bandung. Jurnal AdBispreneur 1(1):85-102. https://doi.org/10.12695/jmt.2014.13.1.2.

Suroso AL, Siahaan R. 2006. Pengaruh stres dalam pekerjaan terhadap kinerja karyawan: studi kasus di Perusahaan Agribisnis PT NIC. JMA 3(1):19-30.

Syahputra BW, Syarifuddin. 2016. Analisis faktor talent management pada kinerja dosen fakultas komunikasi dan bisnis Universitas Telkom. Jurnal eproc of Management 3(2):1759-1767.

Thunnissen M, Arensbergen PV. 2014. A multidimensional approach to talent an empirical analysis of the definition of talent in Dutch Academia. Journal of Management Research 44(2):182-199.

Umar H. 2005. Riset Sumber Daya Manusia dalam Organisasi. Jakarta: PT. Gramedia Pustaka Utama.

Wibowo. 2007. Manajemen Kinerja. Jakarta: Rajawali Pers. 